\title{
HIGHER EMPLOYEE COMMITMENT BY STRONG PEOPLE MANAGEMENT SYSTEM
}

\author{
Anita Kozak ${ }^{1}$
}

Received: March 11, 2020 / Revised: May 8, 2020 / Accepted: June 12, 2020

(C) Association of Economists and Managers of the Balkans, 2020

\begin{abstract}
The purpose of this article is to reveal whether there are any relationships between the components of people management, the dimensions of the employees' commitment and the socio-demographic characteristics of the interviewees. Furthermore, it is also the goal of this article to find out if there are any correlations between the two areas mentioned above. To carry out our research, we performed a primary examination among the students of the Faculty of Economics and Social Sciences at the Eszterházy Károly University in Eger, Hungary. The questionnaire was filled out by 410 people. We applied several mathematical and statistical methods to analyze the data. We can conclude from the results that the respondents' age, position and the size of their salaries are in relation to the judgment of people management and the extent of their commitment. In addition, people management is related to the size of the organization and the commitment is related to the time of employment. During our examinations to reveal the relationships between these two areas, it also turned out that all four components of people management are in connection with the affective, normative, professional, team-oriented and career-oriented types of commitment.
\end{abstract}

Keywords: Employees, Commitment, Management.

JEL Classification M54 $\cdot$ J53 $\cdot$ M12

$\triangle \quad$ kozak.anita@uni-eszterhazy.hu

1 Eszterházy Károly University, H-3300 Eger, Egészségház street 4, Hungary 


\section{INTRODUCTION}

Researchers and professionals have been studying the employees' commitment for decades now. Years ago, when the economic environment was characterized by labor shortage, this was an especially popular field of research. The key question is what sort of workplace environment is needed for the organizations to be able to retain their current labor force so that the labor shortage would not impede their economic performance. Therefore, our examinations were focused on the effects the organizational environment, the processes and the systems have on the employees' commitment. The literature defined the precise content of people management only a few years ago. This includes the HR practices and their enforcement by managers; it is more and more common that the authors studying organizational psychology and management do not examine only one function and its effects but they explore the relationships and consequences of complex systems and phenomena. Since the new people management is still a scarcely examined field, we thought that it was important to reveal its correlations with the employees' characteristics and the relationship with the employees' commitment.

\section{THE CONCEPT OF THE EMPLOYEES' COMMITMENT AND THE RELATED RESEARCH}

Researchers have been actively studying the employees' commitment since the 1960s. According to Becker (1960), the committed conduct develops because the employees realize the losses they would suffer if they left the organization and in order to avoid such losses, they maintain their committed conduct. The consideration and judgment of the losses are influenced by several factors (Parsons 1964), and the early studies related the employees' personal characteristics (Hrebiniak 1971; Hrebiniak - Alutto, 1972), the type of work the employees were doing (Argyris, 1964; Grusky, 1966; Thornton, 1970) and the particular features of their workplaces (Hall - Schneider, 1972; Dubin et al., 1976) to the extent of their commitment.

Beyond the personal characteristics, the type of work and the organizational factors, the researchers started to examine the emotional dimensions of the employees' commitment and they tried to explore these along the organizational integration (Smith et al, 1983). At that time, the commitment examinations were primarily based on the aspect of emotional identification and later they revealed the relationship with several variables, like some factors of the employees' satisfaction with their work (Mowday et al. 1982; Gerhart - Judge, 1991); or workplace ethics and the role of one's work in one's personal life or one's commitment to the trade unions (Morrow, 1983).

Regarding the employees' commitment, the researchers later found out that the employees' commitment to their organization can develop not only emotionally but it can also be affected by other factors and circumstances. One of the related theories was devised by Allen and Meyer (1990). These two authors created the so-called three-component model of commitment: 1. affective commitment, one is committed to the organization emotionally, 2. continuance commitment, one is attached to the organization because this is the best for the individual for some reason and 3. normative commitment, one feels morally obliged to maintain their membership in the organization (Allen - Meyer, 1990).

The two authors found that all three components have a negative correlation with the employees' intention to quit but the affective commitment has the strongest and most favorable correlation with the factors which are the most relevant from the viewpoint of the organization and are important from the employees' viewpoint (Meyer et al. 2002). Thus, the emotional commitment can be regarded as the most valuable organizational conduct. This means an emotional relation- 
ship which is by all means beneficial for the organization (Wasti, 2003). Apart from these three components of commitment, the literature also mentions the professional commitment, the career-oriented and the team-oriented commitments. These types of commitment do not describe the employees' commitment toward the organization. These types of commitment rather express the individual's identification with their chosen profession and their professional community. The professional commitment can be defined as a conduct where the individual is able to identify themselves with their chosen profession, they accept the professional goals and the ethical norms (Mueller et al. 1992). The commitment to one's career is characterized by one's identity awareness, their conviction improvement and the strong participation in one's own active career activities. In other words, this is the individual's commitment toward a career goal (Colarelli - Bishop, 1990). The team-oriented commitment is the individual's commitment toward the goals of the professional workgroup and the values they represent. Therefore, there is some contrast between the career-oriented and the team-oriented commitments since the individual seeks to achieve their own career goals or the goals of their workgroup (Ellemers - Gider, 1998).

\section{The content of people management}

The concept of people management is quite difficult to define. The related literature defines it as the human resources functions and policies and their enforcement by lower-level managers (Caulkin, 2001). These two things must go together since it can be proven that a strong HR system combined with good leaders can create stronger relationships between the HR management, the workplace atmosphere and the employees' performance than these factors separately (Bowen Ostroff, 2004). The correlation between people management and the workplace performance has already been revealed by several researchers. Marchington - Wilkinson (2002) note that between the beginning of the 1990s and the beginning of the 2000s more than 30 papers were published in the US and the UK which confirm the positive correlation between people management and the organizational performance. The authors found that well-functioning people management affects all organizations beneficially, regardless their size, activity and national culture.

The significance of people management is pointed out even by the Leader-Member Exchange Theory (LMX). According to this theory, the quality of the LMX connection and the appreciation of the leader as a human being contribute to the strength of the HR processes (Graen - Uhl-Bien, 1995).

However, people management is not a popular field of research among the experts studying organizational psychology and HR. It might come from this that the authors have reached an agreement on the precise content of people management only in the past years (Table 1).

Table 1. A conceptualization of people management

\begin{tabular}{|c|c|c|c|}
\hline \multicolumn{3}{|c|}{ People management } \\
\hline \multicolumn{2}{|c|}{ Implementation of HR practices } & \multicolumn{2}{c|}{ Leadership behaviour } \\
\hline General practices & $\begin{array}{c}\text { Tailor-made } \\
\text { arrangements }\end{array}$ & Support of commitment & $\begin{array}{c}\text { Support of career } \\
\text { development }\end{array}$ \\
\hline
\end{tabular}

Source: Author's own compilation, based on Knies et al. (2017)

According to the literature, the following HR functions belong to the general practices:

- training and development,

- transition to another job,

- appraisal, 
- compensation and benefits,

- changes in job design (e.g. changes in tasks, career advice),

- vitality (e.g. prevention and health),

- work-life balance (e.g. flexible hours, leave, working from home).

Tailor-made arrangements mean those activities of the immediate superior where the individual living conditions, the status and needs of the employees are taken into account. The support of commitment is the interest (employee-centeredness) the immediate superior shows toward the employees, while the support of career development means the superior's attention toward the development of the employees' careers (Knies et al., 2017).

\section{CORRELATIONS BETWEEN THE EMPLOYEES' COMMITMENT AND PEOPLE MANAGEMENT}

The connection between the components of people management and the employees' commitment was proven by Knies - Leisink (2013). According to their results, there is a positive connection between the commitment and the general HR practices, the tailor-made arrangements and the support of commitment components of people management. The authors used the Allen-Meyer (1990) scale of commitment measurement but they related people management only to the emotional commitment. With reference to the work of Ellemers - Gider $(1998)^{2}$, they did not measure the employees' commitment to the given organization but the commitment to the workgroup. Thus, the word 'organization' was replaced with 'team' in the measurement scale.

\section{METHODOLOGY}

In order to reveal the connection between people management and the dimensions of commitment, we conducted primary examinations among the students of the Faculty of Economics and Social Studies at the Eszterházy Károly University. We sent out the questionnaires online to the students of the faculty and also to the participants of professional trainings organized by the faculty. The data were recorded in September and October 2019. The respondents answered the questions related to people management and organizational commitment on a scale of 1 to $6(1=$ not at all, $6=$ totally $)$. The statements on people management were examined with the help of (Knies et al. 2017), while the items on organizational commitment were examined along the Allen- Meyer's (1990) model's affective continuance and normative commitments. We also used the findings of Ellemers - Gider (1998) on the career-oriented and the team-oriented commitments and the findings of Aranya et al. (1981) on professional commitment. The measurement tools were translated into Hungarian in accordance with the scientific standards. The basic statistical population is 410 individual tests. By combining the questions on people management and the dimensions of commitment, we created new variables. After taking the correlational coefficients into account, we found that these new components (which were combined after averaging the values given to the questions) were suitable to describe people management and the commitment. We applied the methods of descriptive statistics (frequency and average) in our analysis. To reveal the correlations between people management and the dimensions of commitment we used Spearman's rank correlation test. To reveal the connections with the socio-demographic variables, we performed non-parametric tests (Mann-Whitney and Kruskal-Wallis). We considered the results of the statistical tests significant at the value of $p<0,05$. Regarding the sex of the employees involved in the research, we can state that $69.3 \%$ of them ( 284 people) were women and 30.7\% were men (126). According to their ages, 5.6\% of them (23) were born between 1946 and

\footnotetext{
$2 \quad$ According to Ellemers - Gider (1998), the commitment to the workgroup affects the employees' intention to quit
} at a greater extent than the affective commitment to the organization. 
1964 (baby boomers), 38.3\% (157 people) were born between 1965 and 1979 (generation X), 47.6\% (195 people) were born between 1980 and 1995 (generation Y), 8.5\% (35 people) were born after 1995 (generation Z). As for their qualifications, 2.7\% of the respondents (11 people) have completed the elementary school, $39.5 \%$ (162 people) have completed the high school and $57.8 \%$ of them (237 people) have completed higher education. $15.6 \%$ of the respondents ( 65 people) had been working for less than 3 months, $21.2 \%$ of them ( 87 people) had been working for 3 months to 1 year, $22.4 \%$ of them (92) had been working for 1 to 3 years, 40,5\% of them (166 people) had been working for 3 to 6 years at their current workplaces. The sample did not include the individuals working for the same organization for more than 6 years. According to the answers, regarding the judgment of their salaries and compared to similar workplaces, $14.6 \%$ of them ( 60 people) consider their salaries to be above average, $69.3 \%$ ( 284 people) think their salaries are average, while $16 \%$ (66 people) consider their salaries to be below average. Almost a quarter of the respondents $(24.6 \%, 10$ people) work in managerial positions, about three quarters of them (75.4\%, 309 people) are employees. Most respondents (51.2\%, 210 people) work for large businesses, many of them $(26.8 \%, 110$ people) work for medium-sized businesses and only a few of them $(12.7 \%, 52$ people work for small businesses and 9.3\% (38 people) work for micro businesses.

\section{RESULTS}

The answers given to the questions on people management yielded a strongly average value (Figure 1). The lowest value (2.99) was given to the questions on supportive HR practices, while the questions on the tailor-made arrangements and the support of the employees' commitment received the highest values (3.91).

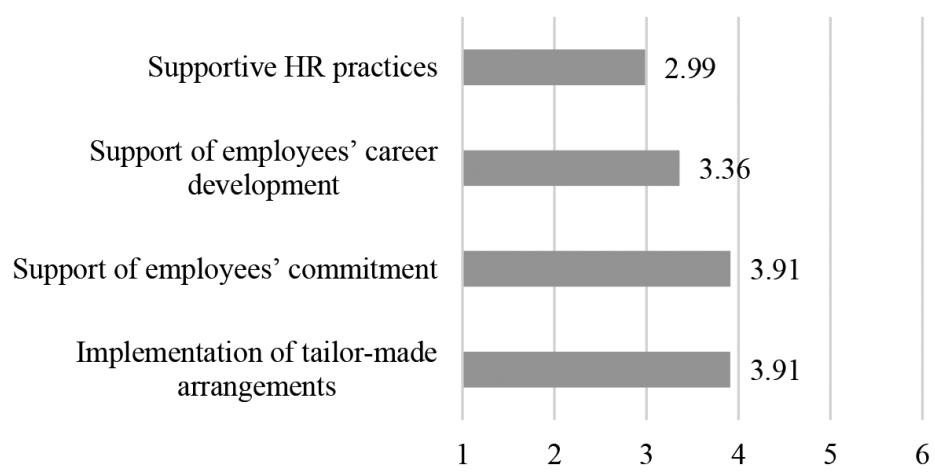

Figure 1. The average values given to the questions of people management Source: Author's own compilation based on own examinations, 2020

The low value for the supportive HR practices might be explained with the fact that in Hungary (in contrast with the US or other European countries), the rate of companies with no HR staff at all is quite high. Also, Hungary is quite behind other countries regarding HR policies and strategies (Kovács, 2017).

During the detailed examinations, it turned out that there are significant differences in the judgment of people management according to the individual socio-demographic variables. The non-parametric tests showed differences in case of the respondents' sex, position, salaries and the size of the organization they work for.

According to our analyses, the older age group the respondents belong to, the more critical they are toward the HR practices. It might be so because most of the older respondents (baby boomers 
and generation X) have already reached the highest point in their careers and they regard the various HR activities less supportive. Those in managerial positions have a more direct experience in their immediate superiors' commitment and career-developing supportive activities than the employees (probably due to their high positions). Those who have higher salaries are also much more satisfied, they gave much higher average scores $(\mathrm{p}=0,000)$ regarding all four people management components. We think it is interesting that the larger a business is, the lower the scores are regarding the tailor-made arrangements and the committed conduct (in case of the latter one, the Kruskal-Wallis test did not show any significant differences along the group-forming factor); however, the results of the average examinations show that the employees gave different scores regarding the activities which support commitment: 4.34 in case of the micro businesses, 4.02 at the small businesses, the medium-sized businesses gave 3.98 and the large businesses yielded 3.80). The background of these results might be that with a smaller number of employees, the employees' individual requests receive much more attention. Also, it is easier to form the employees' emotional commitment toward the organization in a more familial atmosphere. The average scores for the dimensions of commitment are shown in Figure 2.

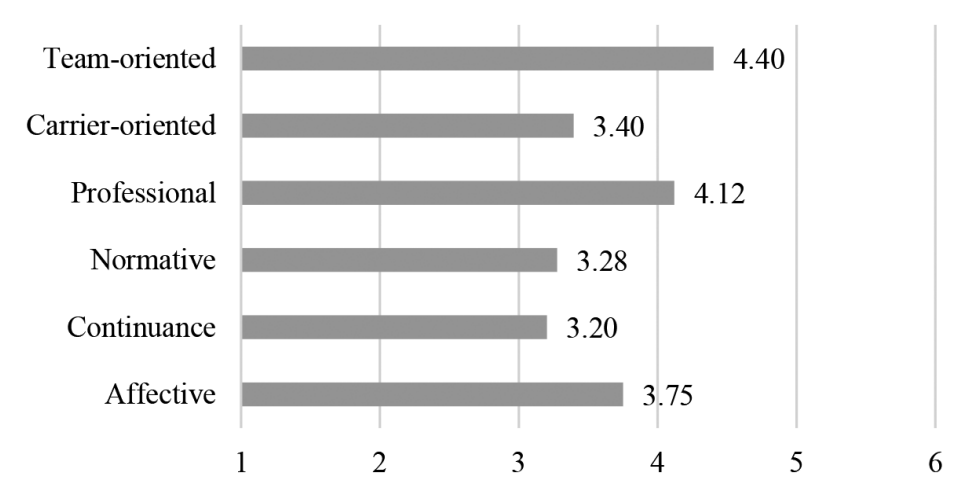

Figure 2. The average scores given to the questions on the dimensions of commitment Source: Author's own compilation, based on own examinations, 2020

Regarding the average scores of the various dimensions of commitment, the team-oriented one received the highest score (4.40), the next one is the professional commitment with 4.12, then the affective one with 3.75 and then the career-oriented commitment with 3.40 . The normative component received 3.28 and the continuance 3.20. In the three-component model, the affective component is considered to be the most valuable one. In view of this, our results are positive. However, the high score for the professional commitment makes the whole picture look different. According to Kallerberg - Berg (1987), there is a contrary relationship between the professional commitment and the commitment toward the organization.

According to our detailed examinations on commitment, there is a correlation between the respondents' age group, their time of employment, position and salaries and the average scores of the dimensions of commitment.

The age-related results have confirmed the findings of other authors. The higher the age is, the higher the scores are for the normative, affective and professional components, while the scores for the career-oriented commitment are lower (Meyer - Allen 1984; Miner 1993, Ellemers Gider, 1998). In case of the time of employment, we can state that the longer the respondents are employed, the stronger the respondents' affective, continuance and normative commitments are. It might be explained with the fact that as time passes, the commitment toward the organization 
becomes stronger. Our calculations show that managers have higher affective, normative, professional and team-oriented commitments. This partly confirms the results of earlier examinations (Liou - Nyhan, 2003), the higher team-oriented commitment might come from the responsibilities of the higher positions. The salary-related examinations show that the respondents with above average salaries have stronger emotional, normative, professional and career-oriented commitments than those who have average or below average salaries. This result is completely in agreement with the results of other authors (Rizqui - Saptoto, 2015; Mosadeghrad - Ferdosi, 2013; Lipinskiene, 2008; Wang et al., 2010; Ellemers - Gider, 1998).

The correlation coefficients describing the connection between the components of people management and the dimensions of commitment are shown in Table 2.

Table 2. Correlation coefficient values between the components of people management and the dimensions of commitment

\begin{tabular}{|c|c|c|c|c|c|c|}
\cline { 2 - 7 } & Affective & Continuance & Normative & Professional & $\begin{array}{c}\text { Career- } \\
\text { oriented }\end{array}$ & $\begin{array}{c}\text { Team- } \\
\text { oriented }\end{array}$ \\
\hline $\begin{array}{c}\text { Tailor-made } \\
\text { arrangements }\end{array}$ & 0.362 & -0.030 & 0.282 & 0.254 & 0.069 & 0.089 \\
\hline $\begin{array}{c}\text { Support of } \\
\text { commitment }\end{array}$ & 0.475 & 0.049 & 0.359 & 0.361 & 0.210 & 0.273 \\
\hline $\begin{array}{c}\text { Support of career } \\
\text { development }\end{array}$ & 0.455 & 0.074 & 0.363 & 0.375 & 0.259 & 0.292 \\
\hline $\begin{array}{c}\text { Supportive HR } \\
\text { practices }\end{array}$ & 0.469 & 0.005 & 0.381 & 0.311 & 0.244 & 0.211 \\
\hline
\end{tabular}

Source: Author's own compilation, based on own examinations, 2020

According to our results, the components of people management and the affective, normative, professional, career-oriented and the team-oriented dimensions of commitment are also connected. We found the strongest connection in case of the affective commitment which is best correlated with the HR practices and the manager's activities supporting commitment and career development (as we mentioned before, the affective commitment is the most beneficial for the organization among the three components of the model). Although the connection is not so strong, the normative and professional dimensions of commitment are also in connection with the components of people management. This might mean that the manager's supportive conduct and the well-functioning HR practices might strengthen the employees' commitment toward the organization and their profession not only emotionally but also morally and professionally. It is a favorable result that the continuance commitment does not have any connection with any of the people management components, since the employees with high continuance commitment would immediately quit for a better job opportunity. It is interesting that the correlation coefficients are almost the same in case of the support of career development, the career-oriented and the team-oriented commitments. This indicates that the support of career development does not exclusively mean higher career-oriented commitment but it might result in stronger team-oriented commitment as well.

\section{CONCLUSION}

This article examines the people management components and the dimensions of the employees' commitment. Our people management-related results point out in general that the organizations our respondents work for should have more supportive and more professional HR practices. It would be worth putting more emphasis on generation management as well. The organizations should create 
processes and tools which could make HR activities more friendly for the older generations (e. g. a system of sharing knowledge within the organization, mentoring programs, integrating the financial and moral appreciation of the employees' loyalty into the company's incentive system etc.). In addition, it would be reasonable if the managers at large companies paid more attention to the activities supporting the employees' commitment and their individual living conditions and circumstances. This could be done by reducing the managers' burden of work and by creating smaller workgroups. The results of our commitment-related examinations have mostly confirmed the results of previously conducted studies in this field. We have found correlations between the respondents' age groups, time of employment, positions and the amount of their salaries and the average scores of the various commitment dimensions. As we have experienced, the younger generations need a different kind of commitment-supporting circumstances and activities than the older generations. As the employees spend more time with the same organization, their intention to leave decreases. The employees' commitment can also be increased in a more direct way, by promoting them to higher positions or by raising their salaries. We managed to prove the correlation between the components of people management and the dimensions of commitment. By surpassing the findings of Knies - Leisink (2013), we can state that in our sample, people management is connected to not only the affective commitment but it is also related to the normative, professional, team-oriented and career-oriented commitments. The well-organized human resources management and its enforcement by lower-level managers may greatly contribute to the high level of the employees' commitment. Thus, it is worth putting more emphasis on the functions and activities and continuously reviewing their efficacy.

One of the limitations of our research is the non-representative sampling. It would be reasonable to explore the sectoral characteristics of people management and to examine the factors affecting them.

\section{ACKNOWLEDGMENT}

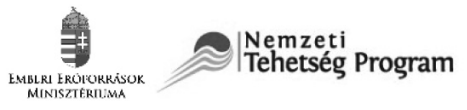

The research was supported by the National Talent Program of the Hungarian Ministry of Human Capacities (NTP-NFTÖ-19).

\section{REFERENCES}

Allen N. J. - Meyer J P (1990). The Measurement and Antecedents of Affective, Continuance and Normative Commitment to the Organization. Journal of Occupational Psychology, 63(1) $1-18$.

Aranya, N. - Pollock, J. - Amernic, J. (1981). An examination of professional commitment in public accounting. Accounting, Organizations and Society, 6(4), 271-280.

Argyris, C. (1964). Integrating the Individual and the Organization. New York: John Wiley

Becker, H. S. (1960). Notes on the concept of commitment. American Journal of Sociology, 66(1), 40-53.

Bowen, D.E. - Ostroff, C. (2004). Understanding HRM-firm performance linkages: the role of the "strength" of the HRM system. Academy of Management Review, 29(2), 203-221.

Caulkin, S. (2001). The time is now, People Management. 30 August 2001, pp. 32-34. Central Arbitration Committee. Annual Report 2000-2001. London

Colarelli, S.M. - Bishop, R.C. (1990). „Career Commitment: Functions, Correlates and Management". Group and Organization Studies, 15 (2), 158 - 78.

Dubin, R., Hedley R. and Taveggia T. (1976). Attachment to work. in: R. Dubin (eds.) Handbook of Work, Organization, and Sociology. Skokie: Rand McNally, 281-341. 
Ellemers, N. - Gider, D. (1998). Career-Oriented Versus Team-Oriented Commitment and Behavior at Work. Journal of Applied Psychology, 83(5), 717-730.

Gerhart, B. A. - Judge, T. A. (1991). Measures of new constructs or old ones? The case of organizational commitment and job satisfaction - CAHRS Working Paper, Ithaca, NY: Cornell University, School of Industrial and Labor Relations, Center for Advanced Human Resource Studies

Graen, G. B. - Uhl-Bien, M. (1995). Relationship-based approach to leadership: Development of leader-member exchange (LMX) theory of leadership over 25 years: Applying a multi-level multi-domain perspective. The Leadership Quarterly, 6(2), 219-247.

Grusky, O. (1966). Career mobility and organizational commitment. Administrative Science Quarterly, 10(4), 488-503.

Hall, D. T. - B. Schneider (1972). Correlates of organizational identification as a function of career pattern and organizational type. Administrative Science Quarterly, (17)3, 340-350.

Hrebiniak, L. G. - Alutto, J. A. (1972). Personal and role-related factors in the development of organizational commitment. Administrative Science Quarterly, 17(4), 555-573.

Hrebiniak, L. G. (1971), A Multivariate Analysis of Professional and Organizational Commitment Orientations Among Teachers and Nurses, Doctoral Dissertation, State University of New York at Buffalo

Kallerberg, A. - Berg, I. (1987). Work and industry: structures, markets and processes. New York: Plenum. 99.

Knies, E. - Leisink, P. (2013). Linking people management and extra-role behaviour: results of a longitudinal study. Human Resource Management Journal, 24(1), 57-76.

Knies, E. - Leisink, P. - Schoot, R. (2017). People management: developing and testing a measurement scale. The International Journal of Human Resource Management. Published online: 23 Oct 2017

Kovács I. É. (2017). Quo vadis HRM? PhD thesis, Szent István University, Gödöllő, Hungary

Liou, K. - Nyhan, R. (2003). Dimensions of organizational commitment in the public sector: An empirical assessment. Public Administration Quarterly, 18(1), 99-118.

Marchington, M. - Wilkinson, A. (2002). People Management and Development 2nd ed. Chartered Institute of Personnel and Development, London

Meyer, J. P., Stanley, D. J., Herscovitch, L., and Topolnytsky, L. (2002), „Affective, continuance, and normative commitment to the organization: a meta - analysis of antecedents, correlates and consequences", Journal of Vocational Behavior, 61 1, 20-52

Miner J. (1993). Role Motivation Theories. Routledge: London

Morrow, P. C. (1983). Concept Redundancy in Organizational Research: The Case of Work Commitment. The Academy of Management Review, (8)3, 486-500.

Mowday, R.T. - Porter, L.W. - Steers, RM. (1982). Employee-organizational linkages. New York: Academic Press

Mueller, C. W. - Wallace, J. E. - Price, J. L. (1992). Employee commitment: resolving some issues. Work and Occupations, 19(3) 211-236.

Parsons, T. (1964). The Social Systems. New York: Free Press

Smith, C. A. - Organ, D. - Near, J. (1983). Organizational citizenship behavior: Its nature and antecedents. Journal of Applied Psychology, 68(4) 653-663.

Thornton, R. (1970). Organizational involvement and commitment to organization and profession. Administrative Science Quarterly, 15(4) 417-427.

Wasti, S. (2003). Organizational commitment, turnover intentions and the influence of cultural values. Journal of Occupational and Organizational Psychology, 76(3), 303-321. 